Mirosław Tragarz ${ }^{1}$

Uniwersytet Papieski Jana Pawła II w Krakowie

\title{
Listy pasterskie w posłudze słowa biskupa Jerzego Ablewicza
}

Żyjemy w ciągle zmieniającym się świecie. Na naszych oczach dochodzi do przeobrażania znanego dotychczas sposobu życia. Zachodzące zmiany dotyczą także komunikacji międzyludzkiej². Do lamusa odchodzą tradycyjne sposoby komunikowania się. Kartki pocztowe, telegramy czy listy zastąpione zostały w dużej mierze przez wiadomości przesyłane drogą elektroniczną. Niemniej jednak w codziennym użyciu pozostają nadal tradycyjne sposoby przekazywania informacji. W dobie poczty elektronicznej zwyczaj pisania listów zaczyna zanikać. Powinniśmy jednak mieć to na uwadze, że list jest oprócz źródła informacji także pewnego rodzaju kroniką i nauczycielem dla odbiorcy. Stał się on również orędownikiem i formą przekazu doświadczenia Boga i wiary ${ }^{3}$.

Celem niniejszego opracowania jest przedstawienie listu pasterskiego jako formy posługi słowa na przykładzie działalności abpa Jerzego

1 Ks. mgr lic. Mirosław Tragarz, kapłan diecezji tarnowskiej, ukończył podyplomowe studia z retoryki na Uniwersytecie Jagiellońskim oraz studia z zakresu homiletyki na Uniwersytecie Papieskim Jana Pawła II w Krakowie. Obecnie pracuje nad doktoratem. E-mail: tragarzm@poczta.onet.pl.

2 Por. P. Thomson, Sposoby Komunikacji Interpersonalnej, Poznań 1998.

3 Por. J. Pałucki, Epistolografia w misyjnej posłudze Kościoła. Zagadnienia wybrane, w: Studia Wrocławskie t. XVII (2015), s. 121-122. 
Ablewicza. Po przedstawieniu autora dzieł epistolograficznych zostanie zarysowany stan badań nad działalnością pisarską abpa Jerzego Ablewicza i dokonana ogólna charakterystyka listów pasterskich. Przedstawimy także źródła, z których czerpał autor listów, oraz pochylimy się nad modelem przepowiadania, jakim posługiwał się tarnowski pasterz.

List pasterski biskupów był i jest nadal jednym z bardzo ważnych sposobów komunikowania się z wiernymi w Kościele katolickim. Dziś widać „stopniowe zmniejszanie się popularności listu, co łączy się z rozwojem innych form komunikacji międzyludzkiej. Specyfiką komunikacji listowej jest przestrzenne (ale i czasowe) oddalenie uczestników. List może być faktem jednorazowym, ale może także stanowić część seryjnej korespondencji, a wtedy - zwłaszcza na wstępie listu - piszący nawiązuje do poprzednich pism" ${ }^{4}$. Niemniej jednak w posłudze biskupów list nadal pozostaje ważnym sposobem przekazu informacji wiernym w Kościołach lokalnych.

$$
*^{*} *
$$

W posłudze biskupiej Jerzego Ablewicza ${ }^{5}$ list pasterski zajmował poczesne miejsce. Pasterz tarnowski dał sie poznać jako mądry i przewidujący duszpasterz oraz chętnie słuchany kaznodzieja. Mając w pełni świadomość nadprzyrodzonej mocy głoszonego słowa Bożego i jego wpływu na duszę ludzką, prowadził wytężoną posługę nauczania, której list pasterski stanowił integralną całość.

4 M. Kuziak, S. Rzepczyński, Jak pisać, Bielsko - Biała 2002, s. 80; por. E. Olinkiewicz, K. Radzmyński, H. Styś, Słownik Encyklopedyczny. Język polski, Wrocław 1999, s. 345-347.

5 „Urodzony 1 XI 1919 roku w Krośnie. Studia filozoficzno-teologiczne odbywał w Seminarium Duchownym w Przemyślu, a po ich ukończeniu otrzymał (5 III 1943) w Brzozowie święcenia kapłańskie. Po święceniach pracował 3 lata jako duszpasterz (Trzcieniec, Przeworsk, Pnikut). Potem odbył studia specjalistyczne na KUL i w 1949 uzyskał stopień doktora filozofii. W latach 1949-1962 wykładał filozofię w przemyskim Seminarium Duchownym, pełniąc tam równocześnie funkcję prefekta studiów oraz wicerektora. 26 II 1962 papieżJan XXIII mianował go biskupem diecezjalnym w Tarnowie. Uroczystość konsekracji biskupiej odbyła się 20 V 1962 w Przemyślu, a 27 V 1962 miał miejsce ingres do katedry tarnowskiej. Godność arcybiskupa otrzymał 10 VI 1987 z rąk papieża Jana Pawła II. Odszedł do Pana 31 III 1990. Dnia 4 IV 1990 został pochowany w krypcie bazyliki katedralnej w Tarnowie". Por. Schematyzm Diecezji Tarnowskiej na rok 1992. Część historyczna, red. J. Rzepa, Tarnów 1992, s. 26. 
Jako pierwszy z tarnowskich biskupów został dnia 6 marca 1981 roku członkiem Kongregacji do spraw Świętych i Błogosławionych ${ }^{6}$. Na osobiste zaproszenie papieża Jana Pawła II wygłosił dla Kurii Rzymskiej „rekolekcje watykańskie" w dniach 8-14 marca 1981 roku, pod znamiennym tytułem „Będziecie moimi świadkami”. Rekolekcje te - jak napisał ojciec święty w liście pożegnalnym - ukazały „całą tajemnicę życia i posługi Arcybiskupa Jerzego"7.

Życie i działalność pisarska arcybiskupa Ablewicza od samego początku była przedmiotem wielu opracowań. Nie sposób bowiem przejść obojętnie obok człowieka, który nie szczędząc sił, pomimo trudnych i niesprzyjających warunków społeczno-politycznych, głosił prawdę Bożą i wynikające z niej niezmienne zasady ${ }^{8}$.

Do obecnej pory brak jednak opracowania listów pasterskich Jerzego Ablewicza z perspektywy homiletyki ${ }^{9}$. Listy pasterskie stanowiły co prawda materiał źródłowy dla innych publikacji ${ }^{10}$, nie mniej jednak nie było do dziś ich krytycznej analizy.

6 Por. B. Kumor, Diecezja tarnowska. Dzieje ustroju i organizacji 1786-1985, Kraków 1985, s. 296.

7 Jan Paweł II, List Ojca Świętego Jana Pawła II przesłany na pogrzeb śp. Arcybiskupa Jerzego Ablewicza, „Currenda” 140 (1990) nr 7-9, s. 385.

8 Pierwszą znaczącą publikacją prezentującą stan badań była praca ks. J. Dudziaka Przełomowe ćwierćwiecze postugiwania bpa Jerzego Ablewicza w Kościele Tarnowskim, opublikowana w 1987 roku w „Tarnowskich Studiach Teologicznych”. Cennym opracowaniem jest również książka ks. Z. Sadki, Percepcja soborowej odnowy liturgicznej w diecezji tarnowskiej za pasterzowania ks. arcybiskupa Jerzego Ablewicza (1962-1990), wydana w 1997 roku w Tarnowie. Równie ważne są także inne publikacje: ks. M. Zająca Katechizacja w diecezji tarnowskiej w okresie posługi biskupiej Jerzego Ablewicza (1962-1990), Tarnów 2000; ks. S. Kądziołki, Prawny aspekt działalności biskupa Jerzego Ablewicza w diecezji tarnowskiej, Kraków 1993 orazks. M. Kluzy Chrześcijańska wizja życia moralnego w nauczaniu Jerzego Ablewicza Biskupa tarnowskiego (1962-1990) Lublin 2001. Pośród innych prac na uwagę zasługują dwie: Pierwsza z nich to zbiór listów pasterskich i odezw arcybiskupa Ablewicza zatytułowany Kościołowi napisz, Katowice 1991. Równie istotna jest druga publikacja: Świadek wierny, Tarnów 2000. Praca ta, pod red. ks. J. Stali, zawiera zbiór artykułów i świadectw osób mających okazję spotkać się bezpośrednio ze swoim pasterzem. Ostatnio ukazały sie drukiem Kazania maryjne abp Jerzego Ablewicza pod red. A. Kokoszki.

9 Tę lukę stara się wypełnić będącą w przygotowaniu wydawniczym książka ks. M. Tragarza Listy pasterskie w biskupiej posłudze Jerzego Ablewicza. Jej przedmiotem są listy pasterskie, za pomocą których abp Jerzy Ablewicz pełnił w swojej diecezji posługę słowa.

10 Wielkopostne listy stanowiły materiał do pracy J. Bulsa, Idea stwórczo-zbawczego powołania człowieka w listach wielkopostnych, Tarnów 1992; na pismach pasterskich w ogól- 


\section{Prezentacja listów pasterskich arcybiskupa Jerzego Ablewicza}

W okresie biskupiego posługiwania arcybiskup Ablewicz skierował do swoich diecezjan 70 listów pasterskich. Sześć z nich jest podzielonych na dwie części - były przeznaczone do odczytania w następujące po sobie niedziele. Wśród analizowanych pism istnieje także jeszcze jeden list pasterski podzielony wyraźnie na dwie części, jednakże w materiale źródłowym przedstawiony został jako jedna całość ${ }^{11}$.

Niniejszy artykuł bierze także pod uwagę Orędzie biskupów przed wyjazdem na Sobór Watykański II ${ }^{12}$ oraz dokumenty zatytułowane Słowo pasterskie $^{13}$. Rozmiar prezentowanych dokumentów i sposób przedstawienia treści zdają się przemawiać za tym, aby nie zaliczać ich - poza wspomnianymi w tekście - do listów pasterskich. Wydaje się, że w dzisiejszej nomenklaturze nazwane zostałyby komunikatami. W materiale źródłowym spotykamy także odezwy wystosowane do wiernych w związku z przeżywanymi w diecezji niedzielami kapłańskimi ${ }^{14}$.

Listy pasterskie powstawały w latach 1962-1989. Ostanie miesiące życia bpa Ablewicza nie przyniosły żadnego listu, choć zdaniem Adama Kokoszki i Antoniego Paciorka zmarły w 1990 roku pasterz tarnowski zamierzał napisać do diecezjan swoje ostatnie słowa ${ }^{15}$. Przy tej okazji warto zauważyć, iż myśl zebrania w jedną całość listów, odezw i modlitw okolicznościowych bpa Ablewicza powzięta została jeszcze za jego życia.

ności opierali się: H. Gawęcka, Model wychowania religijno-moralnego młodego pokolenia w pismach pasterskich abpa Jerzego Ablewicza, Tarnów 2000; S. Kania, Wychowanie w kontekście formacji kapłańskiej: studium na przykładzie nauczania abpa Jerzego Ablewicza, Tarnów 2001; K. Dynarowicz, Moralność teotropiczna w świetle pism pasterskich abpa Jerzego Ablewicza, Tarnów 1994; W. Depa, Program wychowawczy w Seminarium Duchownym w Tarnowie według haset wychowawczych ks. bp Jerzego Ablewicza, Tarnów 1983; K. Franczyk, Maryjny wymiar duchowości w świetle pism abp Jerzego Ablewicza, Lublin 1995; R. Jasiak, Religijny fundament życia moralnego chrześcijan w nauczaniu abp Jerzego Ablewicza, Tarnów 2003; M. Jasiak, Świadectwo chrześcijańskie w świetle nauk rekolekcyjnych bp Ablewicza: „Będziecie moimiświadkami", Tarnów 1999.

11 Por. J. Ablewicz Kościołowi napisz, Tarnów 1991 [dalej: KN], s. 446.

12 Por. KN, s. 24-27.

13 Por. KN, s. 419-485.

14 Por. KN, s. 51-52; 75-76; 100-102; 143-144; 158-160; 198-199; 237-238.

15 Por. Od redakcji, [w:] KN, s. 487. 
Świadczyć to może o wielkim szacunku, jak też i docenianiu kierowanego do diecezjan słowa pasterskiego.

Listy pasterskie stanowią świadectwo wiary i głębokiego umiłowania Kościoła przez bpa Ablewicza. Są wyrazem jego troski o wysoki poziom głoszenia słowa Bożego, jak też odbiciem potrzeby jego pasterskiego serca, które kazało być z Ludem Bożym w najważniejszych dziejowych sytuacjach. Dokonując analizy przedmiotowych listów, możemy wyodrębnić te, które odnoszą się do szeroko rozumianego życia religijnego diecezji tarnowskiej. Możemy wyróżnić pisma dotyczące bezpośrednio przeżywanych koronacji czy obchodów rocznicowych. Stanowią one repetytorium podstawowej wiedzy historycznej o danym sanktuarium, są również ogólnodiecezjalnym zaproszeniem na mające się odbyć uroczystości koronacyjne czy jubileuszowe.

Większość listów pasterskich dotyczy „tarnowskich świętych i błogosławionych". Listy pasterskie zwykle prezentują postać błogosławionego czy świętego, mówią o jego życiu i pracy. Często są wspaniałą lekcją historii podaną w przystępny sposób ${ }^{16}$. Nigdy jednak biskup nie zapomniał, iż list pasterski ma być przekazem Bożych prawd i Bożego słowa.

W analizowanej grupie listów pasterskich spotkać można także te, które powstały w związku z przeżywanymi cyklicznie świętami Bożego Narodzenia ${ }^{17}$ czy Wielkim Postem ${ }^{18}$. Stanowily one wezwanie do prawdziwej radości i świętowania połączonego z głębokim medytowaniem Bożych tajemnic i Bożego słowa. Wielokrotnie na łamach listów pojawiają się także kwestie związane z seminarium i przygotowującymi się do kapłaństwa tarnowskimi klerykami ${ }^{19}$.

16 Por. J. Ablewicz, Znak przeznaczony na powstanie. List pasterski na Wielki Post zapowiadający obchód 900-lecia śmierci męczeńskiej świętego Stanisława ze Szczepanowa (cześć pierwsza do odczytania w II niedzielę Wielkiego Postu 19 II), Tarnów 25 stycznia 1978, [w:] KN, s. 286; J. Ablewicz, Zwycięzca pod mieczem. List pasterski na Wielki Post zapowiadajacy obchód 900-lecia śmierci męczeńskiej świętego Stanisława ze Szczepanowa (część druga do odczytania w III niedziele Wielkiego Postu 26 II), Tarnów 25 stycznia 1978, [w:] KN, s. 291-296.

17 J. Ablewicz, Dobroći ludzkość Boga, List pasterski z okazji świąt Bożego Narodzenia, Tarnów 8 grudnia 1963, [w:] KN, s. 52-56.

18 J. Ablewicz, Ku prawdziwemu człowieczeństwu, List pasterski na Wielki Post, Tarnów 1963, [w:] KN, s. 34-37.

19 Np. J. Ablewicz, Proście Pana Żniwa. List pasterski na Niedzielę Kapłańską 1962 r., [w:] KN, s. 21-23. 
Listy pasterskie bpa Ablewicza to także świadectwo troski o poziom ogólnej wiedzy teologicznej wśród diecezjan. Pasterz tarnowski pisze o problemach wiary ${ }^{20}$, omawia dylematy moralne i stara się przełożyć specjalistyczną wiedzę na język bliski adresatom listów ${ }^{21}$. Bliska słuchaczom jest także problematyka społeczna, poruszana w omawianych listach pasterskich ${ }^{22}$. Wiele uwagi i serca poświęcił biskup sprawie trzeźwości narodu. Wielokrotne apele, znajdujące się w prawie każdym liście pasterskim, zachęty, a także i listy w całości poświęcone potrzebie abstynencji świadczą dobitnie o tym, jak bardzo sprawa ta leżała na sercu biskupowi ${ }^{23}$.

Równie ważna wydaje się sprawa wychowania młodego pokolenia. Widząc w młodzieży przyszłość diecezji, biskup apelował o jej dobre, katolickie wychowanie ${ }^{24}$. Poruszane na łamach listów problemy są aktualne także dziś. Niektóre z nich nie dość, że się nie zdezaktualizowały, to stały się nadzwyczaj ważne w dzisiejszej rzeczywistości. Biskup Ablewicz apelował także o chrześcijańskie przeżywanie niedzieli. Apel ten jest nadal aktualny, a może nawet bardziej konieczny niż w minionym okresie ${ }^{25}$.

Oddzielną grupę listów stanowią te będące świadectwem udziału w obradach Soboru Watykańskiego II $^{26}$, jak też wprowadzenia w życie jego ustaleń. Troszczący się o religijne życie diecezji biskup nie mógł być obojętny na reformy soborowe, wprowadzające zmiany w liturgii Kościoła.

20 J. Ablewicz, Wierzęw Świętych obcowanie. List pasterski wzywający do oddania modlitewnej czci wszystkim, którzy poświęcili swe życie za Ojczyznę, Tarnów, Uroczystość Wszystkich Świętych, 1971, [w:] KN, s. 172-176.

${ }_{21} \mathrm{~J}$. Ablewicz, Rok nadziei. List pasterski na Wielki Post Roku Świętego (część pierwsza), Tarnów 11 lutego 1974, [w:] KN, s. 202-206.

22 J. Ablewicz, Nauczyciele wiary i wspótpracownicy Bożej łaski. List pasterski do rodziców o wychowaniu eucharystycznym, Tarnów 1 marca 1967, [w:] KN, s. 104-107.

${ }_{23} \mathrm{~J}$. Ablewicz, Wobec zagrożenia narodowego bytu. List pasterski na Niedziele Diecezjalnego Apostolatu Trzeźwości, Tarnów 1 września 1980, [w:] KN, s. 336-340.

24 J. Ablewicz, Do takich należy królestwo. List pasterski na Wielki Post o wychowywaniu religijnym i katechezie dzieci przedszkolnych (część druga), Tarnów 11 lutego 1977, [w:] KN, s. 278-282.

25 J. Ablewicz, Niedziela - sakrament zmartwychwstania. List pasterskina Wielki Post, Tarnów 2 lutego 1981, [w:] KN, s. 342-346.

${ }_{26}$ J. Ablewicz, Światto Chrystusa. Orędzie biskupów tarnowskich przed wyjazdem na Sobór Watykański II, Tarnów 11 listopada 1962, [w:] KN, s. 24-27. 
Listy biskupa informują o pracach soborowych, podjętych uchwałach oraz wprowadzają w życie przyjęte reformy ${ }^{27}$.

Listy pasterskie pisane były przez bpa Ablewicza osobiście. W swej pracy biskup korzystał z Pisma Świętego, nauczania ojców Kościoła, dokumentów soborowych czy literatury. W listach pojawiają się także odniesienia do pisarzy chrześcijańskich, liturgii oraz do doświadczenia życiowego własnego czy diecezjan. Pasterz tarnowski posiłkował się także materiałami przygotowanymi przez współpracowników ${ }^{28}$. Listy pasterskie są świadectwem myśli i serca biskupa. Zagadnienia w nich występujące przedstawione są z wielką jasnością i prostotą. Patrząc na nie z dzisiejszej perspektywy, należy zauważyć ich zadziwiającą aktualność w sferze problemów moralno-egzystencjalnych oraz ich wielką systematyczność i precyzję, jeżeli chodzi o podawane treści dogmatyczne. Zauważyć trzeba także bogactwo faktów historycznych czy też odniesień do literatury polskiej i światowej.

Listy pasterskie bpa Jerzego Ablewicza są świadectwem wypełniania przez pasterza tarnowskiego właściwej biskupowi posługi słowa. Dokonana charakterystyka ma służyć ukazaniu ich jako formy biskupiej posługi oraz ogólnej ich prezentacji. Przedstawimy obecnie walory listów pasterskich, stanowiące o ich wyjątkowości i ponadczasowej wartości.

\section{Merytoryczne walory listów pasterskich arcybiskupa Jerzego Ablewicza}

Listy pasterskie mimo upływu czasu nie straciły wiele ze swej wartości i aktualności. Na początku trzeba wymienić jedną z ich nieprzemijających wartości, a mianowicie ich biblijność. Przepowiadanie słowa Bożego ma karmić się Pismem Świętym, a swoją treść winno czerpać ze źródeł

27 J. Ablewicz, Ciało Chrystusa. Amen. List pasterski na Wielki Post, Tarnów 10 marca 1965, [w:] KN, s. 66-69.

28 Materiały takie przygotowywali m.in. ks. dr Adam Nowak i ks. Stanisław Saletnik. Informacja uzyskana w trakcie rozmów odbytych przez autora z w/w pt. kapłanami, 25 czerwca 2008. 
biblijnych $^{29}$. Należy pamiętać także, że winno się ono łączyć z Pismem Świętym, gdyż „zyskuje wówczas wartość słowa Bożego, nabiera nadprzyrodzonego charakteru i skuteczności oddziaływania" ${ }^{30}$.

Biskup Jerzy Ablewicz wzrastał w duchu soboru trydenckiego. Jego przygotowanie do posługi słowa oparte było na nauczaniu i wskazaniach tegoż soboru. Zdobytą wiedzę wykorzystywał w posłudze biskupiej, a zwłaszcza w działalności pisarskiej. Jego listy pasterskie mają klasyczną budowę. Zastosowane w nich środki stylistyczne świadczą o znajomości zasad retoryki.

Jako biskup tarnowski uczestniczył w obradach Soboru Watykańskiego II. W posłudze biskupiej uwzględniał soborowe reformy i wskazania. W głoszeniu słowa opierał się na Piśmie Świętym, Tradycji, liturgii, Urzędzie Nauczycielskim Kościoła, przedstawiając w całości i wiernie tajemnicę Chrystusa $^{31}$. Przez chrzest i sakrament kapłaństwa uczestniczył w misji prorockiej Chrystusa, a dzięki Biblii trwał przy słowie Bożym. Był kaznodzieją - prorokiem, który realizował w życiu ideał proroków staro-i nowotestamentowych ${ }^{32}$. Był oddanym sługą słowa Bożego, wiernym człowiekowi i Ludowi Bożemu.

W listach pasterskich biskup często korzystał z bogactwa tekstów biblijnych. Analiza listów ukazuje doskonałą znajomość Pisma Świętego, które wielokrotnie i ze swobodą przytacza. Przywołuje większe bądź mniejsze fragmenty Ewangelii ${ }^{33}$, Listów $^{34}$ i Dziejów Apostolskich ${ }^{35}$, Apokalipsy $^{36}$.

29 Por. Sobór Watykański II, konst. Dei verbum [dalej: KO], 21-26.

30 K. Panuś, Zarys historii kaznodziejstwa w Kościele katolickim, cz. 1, Kraków 1999, s. 308-309.

31 Por. KPK, kan. 760.

32 Por. J. Kudasiewicz, Kaznodzieja jako prorok, [w:] Sługa Słowa, red. W. Przyczyna, Kraków 1997, s. 79-82.

33 Por. J. Ablewicz, Chrzest naszą Paschą. List pasterski na Wielki Post, Tarnów 22 lutego 1973, [w:] KN, s. 191.

34 Por. J. Ablewicz, Dobroć..., dz. cyt., s. 54.

35 Por. J. Ablewicz, Matka Ludu Bożego. List pasterski z okazji świąt Bożego Narodzenia o Najświętszej Maryi Pannie - Matce Kościoła, Tarnów 8 grudnia 1964, [w:] KN, s. 62.

36 Por. J. Ablewicz, Korona piękności i chwały. List pasterski na uroczystość rekoronacji statuy Matki Bożej w Przeczycy, Tarnów 2 lipca 1975, [w:] KN, s. 248. 
Sięga do Księgi Rodzaju ${ }^{37}$, jak też do Psalmów ${ }^{38}$. Odwołuje się także do starotestamentowych proroków ${ }^{39}$. Nie ma w zasadzie listu ${ }^{40}$, w którym nie byłoby odniesienia do tekstu świętego lub odpowiedniego biblijnego cytatu. W listach pasterskich fragmenty Biblii stanowią czasem motto bądź podbudowę całego przekazu ${ }^{41}$.

Inspirowany żywym w czasie obrad II Soboru Watykańskiego hasłem powrotu do źródeł, bp Jerzy Ablewicz wielokrotnie korzystał z dorobku pisarskiego ojców Kościoła ${ }^{42}$. Starał się przybliżać słuchaczom postaci świętych i błogosławionych. Listy pasterskie są świadectwem wielkiej troski o znajomość u wiernych ich działalności. Pasterz tarnowski, nadając listom powagę i moc, często sięgał do ojców Kościoła: św. Ireneusza ${ }^{43}$ czy św. Augustyna ${ }^{44}$. Czerpie także z nauki wschodnich ojców Kościoła: św. Ignacego Antiocheńskiego ${ }^{45}$,Klemensa Aleksandryjskiego ${ }^{46}$,św. Efrema ${ }^{47}$.

37 Por. J. Ablewicz, Na obraz Kościoła powszechnego. List pasterski na Wieki Post zapowiadajacy IV Synod Diecezji Tarnowskiej, Tarnów 11 lutego 1982, [w:] KN, s. 357.

38 Por. J. Ablewicz, Potrzeba pokuty. List pasterski na Wielki Post, Tarnów 1969, [w:] KN, s. 136.

39 Por. J. Ablewicz, Matka Bolesna w Tysiącletnich dziejach narodu. List pasterski zapowiadający koronację figury Matki Bolesnej w Limanowej, Tarnów 11 sierpnia 1966, [w:] KN, s. 93.

40 Jedyny list biskupa, w którym nie ma ani jednego odwołania się do Pisma Świętego, to pismo W milenijnym hołdzie. List pasterski na milenijnąuroczystość błogosławionej Kingi patronki diecezji tarnowskiej, Tarnów, 7 lipca 1966, [w:] KN, s. 85-88.

41 Por. J. Ablewicz, Potrzeba pokuty..., dz. cyt., s. 135.

42 Zob. J. Szymusiak i M. Starowiejski, Słownik wczesnochrześcijańskiego piśmiennictwa, Poznań 1971. Ojcowie Kościoła zostali wyodrębnieni na podstawie czterech kryteriów: działalności we wczesnym okresie chrześcijaństwa (antiquitas), głoszenia prawowiernej nauki (doctrina ortodoxa), świętości życia (sanctititas vitae), powszechnego uznania przez Kościół (approbatio Ecclesiae).

43 J. Ablewicz, Święty Józef - czyli praca, która uszczęśliwia. List pasterski na 100-letnia rocznicę powstania Zgromadzenia Sióstr świętego Józefa, Tarnów 1984, [w:] KN, s. 398.

${ }_{44} \mathrm{~J}$. Ablewicz, Wychowanie do trzeźwości. List pasterski na Wielki Post, Tarnów 31 stycznia 1972, [w:] KN, s. 181.

45 J. Ablewicz, Pociagająca moc krzyża. List pasterski na 300-tną rocznicę umieszczenia cudownego obrazu Jezusa Ukrzyżowanego w kościele parafialnym w Kobylance, Tarnów 11 kwietnia 1982, [w:] KN, s. 359.

46 J. Ablewicz, Chrzest naszą..., dz. cyt., s. 194.

47 J. Ablewicz, Chrzest nasza...., dz.cyt., s. 190. 
Odwołuje siętakże do św. Cyryla Jerozolimskiego ${ }^{48}$ czy św. Jana Chryzostoma ${ }^{49}$. Analiza listów pasterskich prowadzi do wniosku, że biskup nie miał jakiegoś ,ulubionego" świętego czy pisarza, którego życiorys bądź słowa przytaczałby najczęściej. Niemniej jednak nagromadzenie cytatów czy odwołań do postaci świętych i błogosławionych świadczą o trosce o to, aby wierni znali te postaci oraz naśladowali ich życie w swoim postępowaniu ${ }^{50}$.

Biskup czerpie także z dorobku doktorów Kościoła. Na łamach listów pojawiają się św. Bonawentura ${ }^{51}$, św. Bernard ${ }^{52}$ czy św. Albert $^{53}$. Nie brak oczywiście największego z chrześcijańskich filozofów - św. Tomasza z Akwinu ${ }^{54}$. Biskup odwołuje się do wypowiedzi św. Antoniego ${ }^{55}$, Tomasza à Kempis ${ }^{56}$, św. Franciszka Salezego ${ }^{57}$, św. Ludwika Marii Grignion de Monfort ${ }^{58}$, św. Stanisława ${ }^{59}$ czy św. Alberta Wielkiego ${ }^{60}$. W swoich

${ }_{48}$ J. Ablewicz, Ciało Chrystusa..., dz.cyt., s. 67.

49 J. Ablewicz, Religii i nauce. List pasterski zapowiadający obchód 150-tej rocznicy powstania Seminarium Duchownego w Tarnowie, Tarnów 25 stycznia 1971, [w:] KN, s. 167.

${ }^{50}$ Postępowanie takie zdaje się wypływać ze wskazań dotyczących przytaczania wydarzeń związanych z życiem świętych, jak też ich wypowiedzi. Por. A. Ważyński, Homiletyka, Kraków 1891, s. 232.

${ }^{51} \mathrm{~J}$. Ablewicz, Maryja naszym pocieszeniem. List pasterski zapowiadający koronację cudownego obrazu Matki Bożej pocieszenia w Nowym Sączu, Tarnów 1963, [w:] KN, s. 47.

52 J. Ablewicz, Dar kontemplacji. List pasterski z okazji jubileuszu 750-lecia opactwa Cystersów w Szczyrzycu, Tarnów 16 lipca 1984, [w:] KN, s. 408.

53 J. Ablewicz, Maryjna szkoła serc. List pasterski o oddaniu diecezji tarnowskiej ijej rodzin Niepokalanemu Sercu Najświętszej Maryi Panny, Tarnów 1967, [w:] KN, s. 109.

${ }_{54} \mathrm{~J}$. Ablewicz, Orędowniczka kultury polskiej. List pasterski na 700-lecie założenia klasztoru Klarysek w Starym Saczu, Tarnów 26 czerwca 1981, [w:] KN, s. 348.

${ }_{55}$ J. Ablewicz, Bożego, dz.cyt., s. 63.

56 J. Ablewicz, Ku prawdziwemu człowieczeństwu..., dz.cyt., s. 37.

57 J. Ablewicz, Chrzest nasza...., dz.cyt., s. 191.

$58 \mathrm{~J}$. Ablewicz, Miłość i sprawiedliwość droga prawdziwego człowieczeństwa. List pasterski na rozpoczęcie VII roku Wielkiej Nowenny, Tarnów 1963, [w:] KN, s. 41.

${ }_{59}$ J. Ablewicz, Różańcowy plan uszcześliwiania człowieka. List pasterski zapowiadajacy obchód 50-tej rocznicy koronacji obrazu Matki Bożej Różańcowej w Bochni, Tarnów 15 września 1985, [w:] KN, s. 425.

${ }_{60} \mathrm{~J}$. Ablewicz, Intronizacja nieskończonej mitości. List pasterski na Wielki Post o poświęceniu rodzin Najświętszemu Sercu Jezusa, Tarnów 2 lutego 1975, [w:] KN, s. 243. 
listach cytuje także Tertuliana ${ }^{61}$, który nie jest ojcem Kościoła, ale cenionym pisarzem epoki patrystycznej.

W prezentowanym materiale pisarskim biskup Ablewicz z zamiłowaniem przybliża wiernym życiorysy bądź pojedyncze wydarzenia z życia świętych i błogosławionych. Ten aspekt hagiograficzny widoczny jest zwłaszcza w listach powstałych z racji przeżywanych jubileuszy kanonizacji bądź beatyfikacji związanych z ziemią tarnowską. Tak jest w przypadku św. Kingi ${ }^{62}$, bł. Karoliny ${ }^{63}$, bł. Teresy Ledóchowskiej ${ }^{64}$, św. Stanisława ze Szczepanowa ${ }^{65}$ czy św. Świerada ${ }^{66}$.

Biskup Ablewicz często czerpie z nauczania Magisterium Kościoła. Listy pasterskie, zwłaszcza te z początków działalności biskupiej ${ }^{67}$, omawiają uchwały Soboru Watykańskiego II i informują o wprowadzanych reformach $^{68}$. W swoich listach biskup pisze o grzechu człowieka i jego zgubnych skutkach ${ }^{69}$, o sumieniu ${ }^{70}$, o pokucie jednoczącej człowieka z Bogiem i bliźnim ${ }^{71}$, o miłości i łasce Bożej ${ }^{72}$. Szczególne miejsce zaj-

${ }^{61}$ J. Ablewicz, Ciało Chrystusa..., dz. cyt., s. 69.

62 J. Ablewicz, W milenijnym hołdzie..., dz.cyt., s. 85-88.

63 J. Ablewicz, Duch Święty przewodnikiem na drodze chrześcijańskiej świętości. List pasterski z okazji 60-tej rocznicy śmierci Sługi Bożej Karoliny Kózkówny (część pierwsza), Tuchów 11 czerwca 1974, [w:] KN, s. 212-216.

$64 \mathrm{~J}$. Ablewicz, Chrystusowy nakaz głoszenia ewangelii, List pasterskina Wielki Post o powszechnym obowiązku głoszenia Ewangelii, zapowiadajacy uroczystość ku czci błogosławionej Teresy Ledóchowskiej (cześć pierwsza), Tarnów 4 marca 1976, [w:] KN, s. 258-262.

${ }^{65}$ J. Ablewicz, Znak przeznaczony..., oraz Zwycięzca pod mieczem..., dz. cyt., s. 286-296.

66 J. Ablewicz, Korzenie polskiego tysiaclecia, List pasterski na Wielki Post w 900-tna rocznice kanonizacji świętego Świerada, Tarnów 14 lutego 1983, [w:] KN, s. 378-383.

67 Por. A. Nowak, Jerzy Karol Ablewicz, [w:] Świadek wierny, red. J. Stala, Tarnów 2000, s. 11.

68 Szerzej na temat wprowadzanej reformy liturgicznej pisze Z. Sadko, Percepcja soborowej odnowy liturgicznej w diecezji tarnowskiej za pasterzowania księdza arcybiskupa Jerzego Ablewicza, Tarnów 1997.

69 J. Ablewicz, Nawracajcie się... List pasterskina Wielki Post, Tarnów 20 lutego 1985, [w:] KN, s. 414-417.

70 J. Ablewicz, Sumienie drogowskazem człowieczeństwa. List pasterski na Wielki Post, Tarnów 2 luty 1964, [w:] KN, s. 58-61.

${ }_{71}$ J. Ablewicz, Potrzeba pokuty..., dz. cyt., s. 135-139.

72 J. Ablewicz, Bóg wielki w cierpieniu i mitosierdziu, List pasterski na Wielki Post, Tarnów 7 marca 1984, [w:] KN, s. 390-394. 
mują tematy związane $z$ chrztem świętym ${ }^{73}$, Eucharystią ${ }^{74}$, bierzmowaniem $^{75}$ czy kapłaństwem ${ }^{76}$. Prezentowane $\mathrm{w}$ nich treści podane są w sposób jasny i zrozumiały.

Powyższe stwierdzenia pozwalają nazwać bpa Ablewicza „człowiekiem Kościoła”77. Biskup Ablewicz „żył życiem Kościoła i pragnął, aby życiem Kościoła żył lud Boży w jego diecezji"78. Listy pasterskie są głęboko osadzone w realiach ówczesnego Kościoła. Na ich łamach biskup dzielił się swoim doświadczeniem, nie brak także odniesień do życia innych osób czy też słuchaczy. Biskup znał mentalność diecezjan i starał się to wykorzystać do nawiązania kontaktu ze słuchaczami. Dzielił się swoimi spostrzeżeniami i przemyśleniami oraz swoją wiedzą. Z tego powodu stał się bliski diecezjanom, a listy zyskały bogactwo jego osobowości. Starał się dać odpowiedź na podstawowe pytania egzystencjalne.Czynił to jasno i prosto. Nie szukał wyrafinowanych przykładów, ale odwoływał się do historii z życia, do filmu, prasy czy telewizji. Korzystał z nich w celu podniesienia walorów wypowiedzi i jej uwiarygodnienia. Nie bez znaczenia są także jej funkcje dydaktyczna i argumentacyjna. Nie żył w oderwaniu od rzeczywistości, ale chciał być blisko ludzkich spraw, o czym świadczą cytowane przez biskupa, a kierowane właśnie do niego, listy od diecezjan ${ }^{79}$.

Pisał zawsze z dużym szacunkiem dla człowieka, świadom własnego posłannictwa i ciążącej na nim odpowiedzialności. Należy podkreślić wrażliwość biskupa i jego wielką troskę o trzeźwość narodu. Przy każdej nadarzającej się sposobności apelował o trzeźwość i ukazywał sposoby

73 J. Ablewicz, Tysiacletni dar. List pasterski na Wielkanoc Tysiąclecia Chrztu Polski, Tarnów 1 kwietnia 1966, [w:] KN, s. 80-83; J. Ablewicz, Chrzest naszą Paschą..., dz. cyt., s. 190-195.

74 J. Ablewicz, Ciało Chrystusa..., dz. cyt., s. 66-70.

75 J. Ablewicz, Sakrament dojrzałego wyznawania wiary, List pasterski o przygotowaniu do sakramentu bierzmowania, Tarnów 1968 r., [w:] KN, s. 122-127.

76 J. Ablewicz, Zwiastunowie Chrystusowego pokoju. List pasterski na Niedziele Kapłańska, Tarnów 29 września 1966, [w:] KN, s. 100-102; por. także „Odezwy” na Niedziele Kapłańskie.

77 A. Michalik, Człowiek Kościoła, [w:] Świadek wierny, dz. cyt., s. 94.

78 Por. J. Dudziak, Przełomowe ćwierćwiecze postugiwania bpa Jerzego Ablewicza $w$ Kościele tarnowskim, „Tarnowskie Studia Teologiczne” 10 (1987) 2, s. 5-68.

79 Por. J. Ablewicz, Sakrament..., dz. cyt., s. 122. 
rozwiązania problemów. Wydaje się, że sprawa trzeźwości szczególnie leżała mu na sercu.

W swojej posłudze był „sługą słowa”, świadomym, że „nie jest wyłącznie jakimś religijnym mówcą, nauczycielem prawd wiary, egzegetą tekstów biblijnych, lecz kimś, przez kogo przemawia sam Chrystus"80.

$\mathrm{Z}$ analizowanych pism przebijają silna i dojrzała osobowość biskupa, takt i kultura osobista, jak też dojrzałe i zdrowe relacje z diecezjanami czy duszpasterzami. Można powiedzieć, że biskup Ablewicz przemawiał „w imieniu Chrystusa i w osobie Chrystusa"81. Kiedy taka wiara przenika świadomość i życie kaznodziei, a w przypadku biskupa Ablewicza bez wątpienia tak było, jego słowo staje się świadectwem ${ }^{82}$. Biskup stał się świadkiem. O swojej wierze zaświadczył życiem i tym, co nas szczególnie interesuje - swoim słowem ${ }^{83}$. Jego świadectwo słowa i świadectwo życia szły w parze, ściśle się ze sobą łącząc, będąc jakby „dwiema stronami tego samego medalu" 84 .

\section{Merytoryczne walory listów pasterskich abpa Jerzego Ablewicza}

W swoich listach arcybiskup respektował klasyczny model przepowiadania. Jawi się jako wytrawny kaznodzieja i retor, który znał zasady retoryki. Jego listy miały zwykle budowę kilkuczłonową, odznaczały się logiką i odzwierciedlały krytyczne myślenie autora. Ich kompozycja jest przejrzysta. Tematem są treści teologiczne, katechetyczne, liturgiczne oraz wynikające z aktualnych spraw diecezjalnych.

\footnotetext{
G. Siwek, Wprowadzenie, [w:] W drodze na ambonę, red. G. Siwek, Kraków 1991, s. 12.

Por. Sobór Watykański II, konst. Gaudium et spes [dalej: KDK], 28.

Por. G. Siwek, Wprowadzenie..., dz. cyt., s. 12.

Por. G. Siwek, Kaznodzieja jako świadek, [w:] Sługa Słowa, dz. cyt., s. 83-108.

G. Siwek, Kaznodzieja jako świadek, dz.cyt., s. 99.
} 
We wstępie do listów znajdujemy cytaty zaczerpnięte z Pisma Świętego ${ }^{85}$, czasem krótkie perykopy ewangeliczne przytoczone „własnymi słowami" ${ }^{86}$ bądź fragmenty listów apostolskich ${ }^{87}$. Niekiedy jest to fragment literatury chrześcijańskiej ${ }^{88}$ czy dzieła historycznego ${ }^{89}$. Zastosowane wstępy są zazwyczaj zwięzłe, a czasem nawet bardzo krótkie ${ }^{90}$. Przeważnie nakreślają temat i cel listu, przybliżają do podejmowanego tematu. Niekiedy rozpoczynają od sformułowania pytania ${ }^{91}$ czy zacytowania fragmentu „katechizmu pamięciowego" 92 .

Bezpośrednio po wstępie następuje rozwinięcie tematu, złożone z trzech bądź czterech części. Jest to zwykle proste podanie prawdy teologicznej ${ }^{93}$ lub wyczerpujące przedstawienie od strony historycznej ${ }^{94}$ czy liturgicznej ${ }^{95}$. Biskup nie stroni od śmiałych pytań egzystencjalnych ${ }^{96}$, na które oczekuje odpowiedzi od słuchaczy ${ }^{97}$. Ordynariusz i tutaj okazuje się wytrawnym kaznodzieją i znawcą zasad retoryki. Biskup odwołuje się do bogactwa piśmiennictwa chrześcijańskiego, cytuje dokumenty soborowe i niejednokrotnie przedstawia bogatą hagiografię wybranych świętych czy błogosławionych. Biskup Ablewicz stosuje skutecznie środki argumen-

85 J. Ablewicz, Jubileusz to będzie dla was rzecz święta. List pasterski zapraszający do udziału w centralnej uroczystości jubileuszu 200 rocznicy powstania diecezji tarnowskiej, Tarnów 5 sierpnia 1986, [w:] KN, s. 442.

86 J. Ablewicz, Pozwólcie dzieciom przychodzić do mnie. List pasterski na Wielki Post o wychowywaniu religijnym i katechezie dzieci przedszkolnych (część pierwsza), Tarnów 11 lutego 1977, [w:] KN, s. 274.

87 J. Ablewicz, Korzenie..., dz.cyt., s. 297.

88 J. Ablewicz, Niepokalane piękno Maryi. List pasterski zapowiadający koronację figury Matki Bożej w Lipinkach, Tarnów 24 czerwca 1980, [w:] KN, s. 328.

89 J. Ablewicz, Wobec zagrożenia..., dz. cyt., s. 336.

90 J. Ablewicz, Niedziela..., dz.cyt., s. 342.

91 J. Ablewicz, Duch..., dz.cyt., s. 212.

92 J. Ablewicz, Łaska nawiedzenia. List pasterski zapowiadajacy nawiedzenie bazyliki katedralnej przez Matkę Bożą w Jej częstochowskim obrazie, Tarnów 26 lipca 1982, [w:] KN, s. 369.

93 J. Ablewicz, Sumienie..., dz. cyt., s. 58-61.

94 J. Ablewicz, Znak przeznaczony... cz. 1, Zwycięzca pod mieczem.... cz. 2, dz. cyt., s. 286-296.

95 J. Ablewicz, Ciało Chrystusa..., dz. cyt., s. 66-70.

$96 \mathrm{~J}$. Ablewicz, U stóp krzyża. List pasterski na Wielki Post w 50-tą rocznicę encykliki Piusa XI „Mens nostra”, Tarnów 13 stycznia 1980, [w:] KN, s. 322.

97 J. Ablewicz, Sumienie..., dz. cyt., s. 60. 
tacji, a zastosowany styl i wynikające z niego środki literackie pomagają słuchaczom zrozumieć temat i przyjąć przedstawione zagadnienie ${ }^{98}$.

Zakończenie, wyraźnie oddzielone od poprzedniej części listu" przybiera formę bezpośredniego zwrotu do słuchaczy. Biskup dokonuje w nim krótkiego resumé, odwołując się do głównego, poruszanego w liście zagadnienia. Listy kończy zwykle błogosławieństwo biskupa bądź modlitwa, niejako organicznie związana z zagadnieniem ${ }^{100}$; niekiedy jest to fragment pieśni ${ }^{101}$.Zakończeniem jest czasem jedno podsumowujące zdanie ${ }^{102}$. Listy pasterskie napisane są plastycznym i obrazowym językiem. Zastosowane zwroty uchroniły się przed „zębem czasu”, a niektóre archaiczne już dziś zwroty świadczą o naturalnym procesie ewolucji języka.

Formalna analiza listów pasterskich wykazuje, że zostały one napisane językiem dostosowanym do poziomu intelektualnego wiernych. Nigdzie nie mamy do czynienia z przekazem „nowinkarskim” lub niepopartym autorytetem Kościoła. Prezentowane oficjalne dokumenty Kościoła nadają listom powagi i legitymująje jako zgodne z nauczaniem Kościoła powszechnego ${ }^{103}$. Biskup zachęcał do podjęcia trudu realizowania wskazań w życiu osobistym. Pragnął, aby omawiane treści zostały przyjęte przez diecezjan i stały się integralnym elementem ich życia wiary.

\section{Podsumowanie}

Listy pasterskie zajmują bardzo ważne miejsce w posłudze słowa abpa Jerzego Ablewicza. Stanowią źródło informacji religijnej i są przejawem troski o poziom moralny diecezjan. Wskazują na pełnienie posługi słowa w oparciu o źródła biblijne i nauczanie Magisterium Kościoła.

\footnotetext{
98 Zob. D. Zdunkiewicz-Jedynak, Językowe środki perswazji w kazaniu, Kraków 1996.

99 Bywajednak czasem, że brakuje wyróżnienia. Por. J. Ablewicz, Zwycięzca pod mieczem..., dz. cyt., s. 296.

100 J. Ablewicz, Rok nadziei..., dz. cyt., s. 206.

101 J. Ablewicz, Duch..., dz.cyt., s. 220.

102 J. Ablewicz, Świętemu Stanisławowi w hołdzie. List pasterski zapowiadajacy pielgrzymkę na Wawel i Skatkęna zakończenie Roku Świętego Stanisława, Tarnów 1 września 1979, [w:] KN, s. 320.

103 Por. Sobór Watykański II, dekret Presbyterorum ordinis, 4, Sobór Watykański II, konst. Sacrosanctum Concilium, 35, KO 24.
} 
Redagowane w oparciu o klasyczny model przepowiadania, napisane językiem dostosowanym do poziomu słuchaczy, mówią także o takcie i kulturze osobistej biskupa. Stanowią istotny element biskupiej posługi sprawowanej w poczuciu wielkiej duszpasterskiej odpowiedzialności za powierzonych diecezjan. 


\section{Summary}

\section{Listy pasterskie w posłudze słowa biskupa Jerzego Ablewicza}

List jako forma komunikacji interpersonalnej znany był już w najstarszych kulturach i cywilizacjach. Ma on także swoją chrześcijańską genezę i etymologię. To także forma przekazu doświadczenia Boga i wiary. List pasterski odegrał bardzo ważną rolę w posłudze słowa biskupa tarnowskiego Jerzego Ablewicza. Jest on autorem 70 listów pasterskich skierowanych do diecezjan podczas jego 28-letniej posługi biskupiej. Odnoszą się do szeroko rozumianego życia religijnego, przeżywanych koronacji czy obchodów rocznicowych. Stanowią swoiste repetytorium wiedzy historycznej. W większości dotyczą tarnowskich świętych i błogosławionych. Są przejawem troski biskupa o poziom wiedzy teologicznej i postawę moralną diecezjan. Stanowią także świadectwo udziału biskupa w obradach Soboru Vatykańskiego II. Omawiane dzieła epistolograficzne przygotowywane były przezarcybiskupa Jerzego Ablewicza i opierały się naźródłach biblijnych, dorobku ojców Kościoła i Magisterium. Przygotowane w oparciu o klasyczny model przepowiadania, mają walory komunikacyjne i pedagogiczne. Arcybiskup Jerzy Ablewicz na łamach swoich dzieł jawi się jako człowiek wielkiego taktu i kultury, który w swojej posłudze doskonale korzystał z listu pasterskiego jako formy posługi słowa i przekazu doświadczenia Boga oraz własnej wiary.

Słowa kluczowe: egzegeza, epistolografia, ojcowie Kościoła, wiara

\section{Pastoral letters in the ministry of the archbishop, Jerzy Ablewicz}

Writing letters as a form of interpersonal communication has been known in ancient cultures and civilizations. It also possesses its own Christian origins and etymology. It is also a source of experiencing God and faith.

The pastoral letter played a very important and crucial role in the ministry of the bishop, Jerzy Ablewicz. He is the author of 70 pastoral letters aimed at people of the diocese during his twenty-eight-year-old bishop ministry. These pastoral letters concern not only the widely understood religious life but also religious coronations and anniversary celebrations.

The letters also constitute peculiar and individual seminar of historical knowledge. Most of them refer to the saint and the blessed of Tarnów. Not only are they the manifestation of the bishop's concern regarding the level of theological knowledge but also the moral conduct of the diocese people. They are also the testimony of the bishop's participation in the Second Vatican Council.

The discussed works of the epistolography were prepared by the archbishop, Jerzy Ablewicz and were based on biblical sources of Church Fathers and Magisterium. Based on a classical model of prophecy, they encompass both comprehensible and also 
pedagogic values. In the pages of his works, the archbishop, Jerzy Ablewicz, comes into sight as the tactful, well-mannered shepherd. In his ministry the archbishop took great advantage of pastoral letters as a form of word ministry and the source of experiencing God as well as his own faith.

Keywords: the exegesis of religious texts, epistolography, Church fathers, faith

\section{Bibliografia}

Ablewicz J., Kościołowi napisz. Listy, odezwy, modlitwy okolicznościowe (1962-1989), red. A. Kokoszka, A. Paciorek, Katowice 1991.

Bulsa J., Idea stwórczo-zbawczego powołania człowieka w listach wielkopostnych, Tarnów 1992.

Depa W., Program wychowawczy w Seminarium Duchownym w Tarnowie według haset wychowawczych ks. bp Jerzego Ablewicza, Tarnów 1983.

Dudziak J., Przełomowe ćwierćwiecze posługiwania bpa Jerzego Ablewicza w Kościele tarnowskim, „Tarnowskie Studia Teologiczne” 10 (1987) 2, s. 5-68.

Dynarowicz K., Moralność teotropiczna w świetle pism pasterskich abp Jerzego Ablewicza, Tarnów 1994.

Franczyk K., Maryjny wymiar duchowości w świetle pism abpa Jerzego Ablewicza, Lub$\operatorname{lin} 1995$.

Gawęcka H., Model wychowania religijno-moralnego młodego pokolenia w pismach pasterskich abpa Jerzego Ablewicza, Tarnów 2000.

Jan Paweł II, List Ojca Świętego Jana Pawła II przesłany na pogrzeb śp. Arcybiskupa Jerzego Ablewicza, „Currenda” 140 (1990), nr 7-9, s. 385-386.

Jasiak M., Świadectwo chrześcijańskie w świetle nauk rekolekcyjnych bp Ablewicza: „Będziecie moimi świadkami”, Tarnów 1999.

Jasiak R., Religijny fundament życia moralnego chrześcijan w nauczaniu abp Jerzego Ablewicza, Tarnów 2003.

Kania S., Wychowanie w kontekście formacji kapłańskiej: studium na przykładzie nauczania abp Jerzego Ablewicza, Tarnów 2001.

Kazania maryjne abp Jerzego Ablewicza, red. A. Kokoszka, Tarnów 2016.

Kądziołka S., Prawny aspekt działalności biskupa Jerzego Ablewicza w diecezji tarnowskiej, Kraków 1993.

Kluz M., Chrześcijańska wizja życia moralnego w nauczaniu Jerzego Ablewicza Biskupa tarnowskiego (1962-1990), Lublin 2001.

Kodeks prawa kanonicznego.

Kudasiewicz J., Kaznodzieja jako prorok, [w:] Sługa Słowa, red. W. Przyczyna, Kraków 1997, s. 64-83.

Kumor B., Diecezja tarnowska. Dzieje ustroju i organizacji 1786-1985, Kraków 1985.

Kuziak M., Rzepczyński S., Jak pisać, Bielsko-Biała 2002.

Michalik A., Człowiek Kościoła, [w:] Świadek wierny, red. J. Stala, Tarnów 2000, s. 89-104.

Nowak A., Jerzy Karol Ablewicz, [w:] Świadek wierny, red. J. Stala, Tarnów 2000, s. 9-11. 
Olinkiewicz E., Radzymińska K., Styś H.,Język polski: słownik encyklopedyczny, Wrocław 1999.

Pałucki J., Epistolografia w misyjnej posłudze Kościoła. Zagadnienia wybrane, „Studia Wrocławskie" 17 (2015), s. 121-133.

Panuś K, Zarys historii kaznodziejstwa w Kościele katolickim, cz. 1, Kraków 1999.

Sadko Z., Percepcja soborowej odnowy liturgicznej w diecezji tarnowskiej za pasterzowania ks. arcybiskupa Jerzego Ablewicza (1962-1990), Tarnów 1997.

Schematyzm Diecezji Tarnowskiej na rok 1992. Część historyczna, red. J. Rzepa, Tarnów 1992.

Siwek G., Kaznodzieja jako świadek, [w:] Sługa Słowa, red. W. Przyczyna, Kraków 1997, s. 83-108.

Siwek G., Wprowadzenie, [w:] W drodze na ambonę, red. G. Siwek, Kraków 1991.

Sobór Watykański II, Konstytucja Dei verbum.

Szewczyk W., Myśleć po Bożemu, z entuzjazmem, [w:] Świadek wierny, red. J. Stala, Tarnów 2000, s. 452-456.

Szymusiak J., Starowiejski M., Stownik wczesnochrześcijańskiego piśmiennictwa, Poznań 1971.

Thomson P., Sposoby komunikacji interpersonalnej, Poznań 1998.

Ważyński A., Homiletyka, Kraków 1891.

Winczura Ł., Bibliografia pism arcybiskupa Jerzego Ablewicza, [w:] Świadek wierny, red. J. Stala, Tarnów 2000, s. 12-43.

Zając M., Katechizacja w diecezji tarnowskiej w okresie postugi biskupiej Jerzego Ablewicza (1962-1990), Tarnów 2000.

Zdunkiewicz-Jedynak D., Językowe środki perswazji w kazaniu, Kraków 1996. 